\title{
Decomposed solid waste impact on soil shear strength and California bearing ratio
}

\author{
Ayininuola, G.M. \\ (Department of Civil Engineering, University of Ibadan, Ibadan, Nigeria)
}

\begin{abstract}
The study examined the impact of leachate from decomposed solid waste at an open dumpsite on the vicinity soil shear strength and California bearing ratio (CBR,) and suitability of such site for construction purpose. Soil samples were taken from three sections of an old solid waste dumpsite operated by the University of Ibadan, Ibadan for laboratory study. The properties determined were particle size, Atterberg limits, compaction test, and CBR and shear strength for two seasons. The CBR and cohesion c' at the core areas of dumpsite were found to be higher than those of surrounding soils that were a little far from dump areas. This shows that buildings and roads can be erected upon unused dumpsite; the soil is structurally safe.
\end{abstract}

Keywords: Leachate, Open dumpsite, California bearing ratio, Shear strength.

\section{INTRODUCTION}

The study of engineering behavior of different soils is extremely important in Civil Engineering discipline. This is due to the fact that nearly all engineering structures such as buildings, roads, bridges, monuments etc. have to be rested on and founded on ground surface or beneath. The substructure or foundation portion of civil engineering structure needs to be taken below ground and rested on soil in such a manner that the structure will not tilt or settle due to failure of soil beneath. The strength of soil to withstand load under different site condition becomes an important factor.

The production of solid waste has been associated with human settlement. When humans lived in small communities, the solid waste generated could easily be burned or buried. The potential impact of the waste then was very minor because the material was rarely hazardous and was not being produced in large quantities. As towns and cities developed, people began to live in densely populated areas, and the production of waste has become health problem. These threats are even more in the developing countries where large quantities of solid waste are dumped haphazardly, thereby, putting pressure on scarce land and water resources and at the same time affecting the properties of soils [1]. In response to this threat, towns and villages designated dumping area for solid waste management usually at the outskirts of the towns. Since the beginning of civilization, land disposal (i.e. open dumping and landfilling) and land application had been primary means of human solid and liquid waste management. However, improperly operated or maintained waste disposal sites had become the major source of various hazardous materials, contaminating water, air and soil in vicinity [2]

A refuse or solid waste dumpsite is an open land mass where solid wastes are allowed to decompose, burned and probably treated. A large number of adverse impacts occurred from waste disposal operations. These impacts varied from fatal accidents, infrastructural damage, pollution of local environment such as contamination of groundwater and or aquifers by leakage and residual soil contamination during landfill usage as well as after its closure [3]. Open dump is still predominant in Nigeria. About $70 \%$ of the total municipal solid wastes are being disposed in several hundreds of dumpsites spreading all over the country. Environmental law was enacted and forced local authorities to take responsibility of the waste management in their territory [4].

The previously used sites are now being used to provide basic infrastructures such as buildings, roads etc. to meet the demand arising from the increasing population. Recently, the three tiers of Government (Federal, State and Local) are making reforms about bringing into use the existing or old dumpsites into productive use while safeguarding the environment, public health and safety. It is important to check if solid wastes will not affect soil geotechnical properties before erecting structures on old dumpsites. The previously used waste disposal sites are vacant with potential for redevelopment. They might have been contaminated and hence there is need to ascertain to what extend the level of contamination would have on soil strength and ability to resist axle loads from vehicles before structures are erected on them. While many researchers have worked on the characterization and management of Municipal Solid Waste in Nigeria and their effect on groundwater, little attention has been given to the effect of these wastes on the geotechnical properties of soils [5, 6, 7 and 8]. The study focused on impact of leachate from decomposed solid wastes at dumpsite on soil geotechnical properties. 


\section{MATERIALS AND METHOD}

The open dumpsite selected for study was owned by the University of Ibadan, Ibadan, Nigeria. The site is located at outskirt of Ajibode village near the University campus. One of the operators of the dumpsite confirmed that the site has been in existence for over thirty years. At the dumpsite three dump sections were identified and tagged A, B and C. At each section, a core point (centroid of dump) was identified by visual inspection as point 1 and two other points were selected away from heap of refuse dump either side of point 1 tagged as points 2 and 3. Therefore, at each section, three sampling points were established. For instance at section A, the established sampling points were A1, A2 and A3 (Fig. 1). During sample collection, the decomposed materials left were removed and top soil excavated up to about $1.5 \mathrm{~m}$ below ground surface before enough soil sample was taken for laboratory work. The samples collection was done during the peak period of dry and wet seasons. Soil geotechnical properties monitored were particle size analysis, Atterberg limits, compaction test, shear strength and California bearing ratio (CBR) in accordance with standard [9].

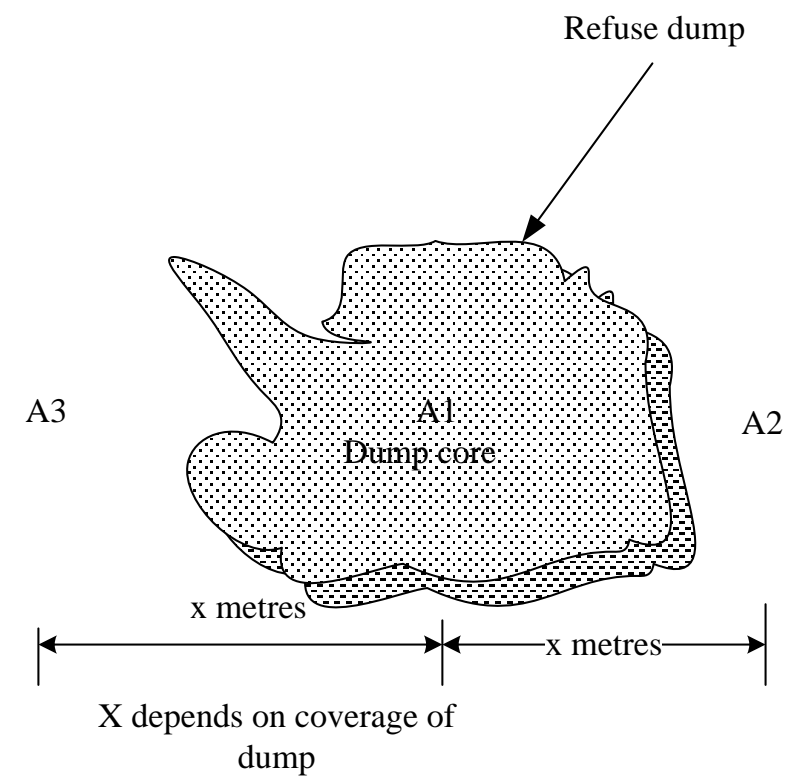

Fig. 1: Pictorial representation of typical collection point at dump section

\section{RESULTS AND DISCUSSION}

Soil samples obtained at the three sections during the drought and wet season revealed that the soil at the dumpsite was well-graded with sand as predominant particle present. The liquid limits ranged from $31 \%$ to $35 \%$ while plastic limits ranged from $9 \%$ to $20 \%$. The optimum moisture content (OMC) values obtained were used to prepare soil samples for CBR and shear strength determination. The CBR and shear strength parameters (c' and Ø') values obtained for each sample were displayed in Tables1 and 2. In all the three sections, the values of ' $c^{\prime}$ and $\mathrm{CBR}$ at the sectional cores were highest. This shows that the leachate produced from decomposed refuse infiltrated into soil, aids cementation of soil particles and also improves the bonds among particles. Leachate contains a lot of anions and cations. The cations are exchangeable types leading to replacement of mono cations in soil with dia and tri cations that will produce strong bond among soil particles. All these would account for the highest values of CBR and c' obtained at sectional cores. Even though the sectional cores had the highest values of c' and CBR, the values for the two seasons varied. The dry season values were higher than those of wet season. During wet season, rain that fell on the waste aids dilution of leachate produced and as such, the concentration of ions in the leachate would be lowered that those of dry season and hence the reduction in c' and CBR observed.

Since the CBR and c' at the sectional cores of the dumpsite were higher than the values obtained at the either sides, this development will enhance the bearing capacity of the soil at the dumpsite. Consequently, roads and buildings can be erected on such soil. The friction values $\varnothing$ ' for the soil samples followed irregular pattern and very difficult for comparison to be made. 
Table 1: Shear strength and CBR of soil samples collected during dry season

\begin{tabular}{lllll}
\hline \hline $\begin{array}{l}\text { Dump } \\
\text { section }\end{array}$ & $\begin{array}{l}\text { Sample } \\
\text { location }\end{array}$ & \multicolumn{2}{c}{ Shear strength } & CBR \\
& $\mathrm{c}^{\prime}\left(\mathrm{kN} / \mathrm{m}^{2}\right)$ & $\Phi^{\prime}\left(^{\circ}\right)$ & \\
\hline \multirow{3}{*}{$\mathrm{A}$} & $\mathrm{A} 1$ & 100 & 20 & 86 \\
& $\mathrm{~A} 2$ & 72 & 16 & 82 \\
& $\mathrm{~A} 3$ & 68 & 25 & 84 \\
$\mathrm{~B}$ & $\mathrm{~B} 1$ & 84 & 18 & 85 \\
& $\mathrm{~B} 2$ & 80 & 12 & 78 \\
& $\mathrm{~B} 3$ & 60 & 24 & 80 \\
& $\mathrm{C} 1$ & 95 & 31 & 81 \\
$\mathrm{C}$ & $\mathrm{C} 2$ & 60 & 24 & 78 \\
& $\mathrm{C} 3$ & 70 & 20 & 76 \\
\hline \hline
\end{tabular}

Table 2: Shear strength and CBR of soil samples collected during wet season

\begin{tabular}{lllll}
\hline $\begin{array}{l}\text { Dump } \\
\text { section }\end{array}$ & $\begin{array}{l}\text { Sample } \\
\text { location }\end{array}$ & \multicolumn{2}{c}{ Shear strength } & CBR \\
& $\mathrm{c}^{\prime}\left(\mathrm{kN} / \mathrm{m}^{2}\right)$ & $\Phi^{\prime}\left({ }^{\circ}\right)$ & \\
\hline \multirow{2}{*}{$\mathrm{A}$} & $\mathrm{A} 1$ & 98 & 17 & 82 \\
& $\mathrm{~A} 2$ & 66 & 18 & 76 \\
& $\mathrm{~A} 3$ & 63 & 24 & 68 \\
$\mathrm{~B}$ & $\mathrm{~B} 1$ & 78 & 20 & 80 \\
& $\mathrm{~B} 2$ & 72 & 14 & 76 \\
& $\mathrm{~B} 3$ & 57 & 22 & 72 \\
& $\mathrm{C} 1$ & 92 & 25 & 75 \\
$\mathrm{C}$ & $\mathrm{C} 2$ & 58 & 24 & 65 \\
& $\mathrm{C} 3$ & 65 & 22 & 70 \\
\hline \hline
\end{tabular}

\section{CONCLUSION}

The geotechnical properties of soil at dumpsite used for over thirty years were studied. The experimental study showed that the soil properties such as CBR and shear strength at dumpsite were far better than those of adjacent surrounding soils that revealed positive effect of leachate from decomposed waste on soil.

\section{Books:}

\section{REFERENCES}

[1] H.S. Nanda, Impact of municipal solid waste disposal on geotechnical properties of soil, Proc. of Indian Geotechnical Conf. December 15-17, Kochi, 2011, 715-716.

[2] K. Ikehata, and Y. Liu, Land disposal of wastes (Encyclopedia of Environmental Health, 2011).

[3] United Nations Environment Programme, Solid waste management ( Regional Overviews and information Sources, 2005).

[4] NRI, Rehabilitation of dumpsite into integrated waste management (Thailand: http://3rkh.net/3rkh/files/NRIThailand\%289\%29.pdf, 2011).

[5] J.C. Agunwamba, N. Egbuniwe, and T.C. Ogwueleka, Least cost management of solid waste collection, Journal of Solid Waste Technology and Management, 29(3), 2003, 154- 167

[6] T.C. Ogwueleka, Municipal solid waste characteristics and management in Nigeria, Iran Journal Environmental Health Science Engineering. 6(3), 2009, 173- 180.

[7] A. B. Nabegu, An analysis of municipal solid waste in Kano metropolis Nigeria, Journal of Human Ecology, 31(2), 2010, 111-119.

[8] O.I. Nkwachukwu, N.I. Chidi, and O.C. Kanno, Issues of roadside disposal habit of municipal solid waste, environmental impacts and implementation of sound management practices in developing country, Nigeria, International Journal of Environmental Science and Development, 1 (5), 2010, 409-418.

[9] BS 1377 Methods of test for Soils for civil engineering purposes (England: British Standards Institution, 1998). 